\title{
Good Governance and the Challenges of Insecurity on Secondary School Administration in Nigeria
}

\author{
Chinelo Maryann Chiemeka-Unogu Ph.D \\ Department of Educational Management, Ignatius Ajuru University of Education, \\ Port Harcourt, Nigeria \\ *E-mail: chinelo_chiemeka@yahoo.com
}

\begin{abstract}
Good governance relates to use of state resources and power fairly and equitably to achieve and promote the well being of citizens of a nation. When power and resources are not well managed for the welfare of the citizens, it fosters problems. Insecurity has paralysed educational system in Nigeria. Secondary school administration is facing numerous challenges as a result of insecurity in Nigeria. The paper associated insecurity in Nigeria to lack of good governance in the country. The paper identified corruption, unemployment, ethno-religious conflicts and illegal armed groups as challenges of insecurity in Nigeria. The paper focused on good governance and challenges of insecurity in secondary school administration. To address the challenges of insecurity on secondary school administration it was suggested that competent school administrators be appointed to ensure safety in schools.

Keywords: Good Governance; Insecurity; Secondary School Administration.
\end{abstract}

DOI: $10.7176 / \mathrm{JEP} / 13-6-04$

Publication date: February $28^{\text {th }} 2022$

\section{Introduction}

Governance relates to the management of society by the people or the exercise of authority to manage a country's affairs and resources (Simonies, 2004). It refers to government providing infrastructures fairly and equitably to the citizens. Good governance involves the process by which the government engages communities. Without good governance, a country makes itself vulnerable to diverse forms of insecurity (Aina, Gana \& Ibitomi, 2017). The perpetrators of acts of insecurity have offered reasons of marginalization of themselves and communities by government. They are seeking tangible demonstration of government commitment to improving their lives in the areas of public goods such as roads, educational opportunities, health services and communication infrastructure.

The lives and material resources lost to insecurity in the past few years are immeasurable. According to data analysed by HumAngle (2021), a security monitoring group, an estimated number of 6000 lives were lost in Nigeria between January 1 and June 30, 2021. Consequently, parents have withdrawn their wards from schools while some State Governments have closed down schools for fear of lives and properties.

The 1999 Constitution of the Federal Republic of Nigeria specifically states that the welfare of the people shall be the primary purpose of government. The government has failed in the constitutional responsibility to provide a secured and safe environment for lives of students and their teachers in educational institutions. The primary objective of the school administrator as a government representative in the school is to ensure the security and welfare of the staff and students under his care. It seems the school administrators are incapable of guaranteeing the safety and security of those under them. There have been reports of continued abductions of school children in the primary schools, secondary schools and students in tertiary students and their teachers in Nigeria.

\section{Concept of Good Governance}

Governance is the way in which government exercise power for the management and distribution of a country's social and economic resources. Governance entails acting with transparency and accountability in the selection and implementation of development projects. Good governance relates to use of state resources and power accountably to achieve and promote the well being of the citizenry. There are indicators to reveal that the lack of good governance in Nigeria is breeding insecurity. The insecurity is manifested through kidnapping, banditry and other forms of terrorism crippling the educational system. The political leaders give privileges and undue advantage to their families, friends, associates and men and women from their geo-political zone in the distribution of public resources (Adeosun, 2012.)

Good governance in education relates to the way a school system composes policies, produces funds and expands funds, teacher preparation for teaching scheming curricular and administration of school population. Good governance is one of the keys for achieving educational objectives because it comprises the responsibilities of government, policy makers, educational service providers, parents and citizens.

\section{Challenges of Insecurity in Nigeria}

Omede (2011) viewed security as a dynamic condition which involves the relative ability of a state to conquer 
threats to its core values and interests. On the contrary, insecurity is concerned with negative feeling of fear, anxiety, uncertainty and injustice among others (Nwosu, Ukwunna, Ebokaiwe \& Ukwunna (2019). Achumba, Ighomereho and Akpor-Robaro (2013) considered insecurity as a condition where there exists a vulnerability to harm, loss of life, property or livelihood.

Ishaq, Musa and Abdulhafiz (2019) asserted that failure of government to provide the basic human needs of their citizens, ethnic disagreement and national resources contentions as some of the factors responsible for insecurity in Nigeria. Otite (2012) submitted that the state of insecurity in Nigeria could be attributed to security lapses on the part of security agents.

Some of the major causes of insecurity confronting Nigeria as identified by Okonkwo, Ndubuisi and Anagbogu (2015) include:

- $\quad$ Ethno-religious Conflicts

- Weak security system

- Unemployment/Poverty

- Porous Borders

- Systemic and political corruption

Udoh (2015) noted that there has been dramatic increase in violence and terrorism in Nigeria and examined some factors as causes of insecurity in Nigeria.

- Proliferation of arms and ammunition

- Illegal Armed groups

- Oil bunkering

- Labour activities

- Militancy

- Kidnapping

- Religious fanaticism

- Fear and distrust on government

\section{Boko Haram Insurgency}

Boko Haram insurgency started with grievances that mobilized communities in the Northern parts of Nigeria to propagate extremists' ideology and violence. Insurgency can be defined as organized movement that has the aim of overthrowing a constituted government through subversive means and armed conflict (Ukpong-Umo, 2016). The Boko Haram sect commenced operation in 2002 in a non-violent manner with campaign against western education which influenced the name Boko Haram meaning western education is forbidden.

In 2004, the Boko Haram insurgency started with activities involving kidnapping school girls and boys, assassinations, invading communities, burning religious centers and bombing defenseless civilians with a promise that the war will continue as long as educational system remained westernized. On February 28, 2012, the insurgents burnt down Gomari Primary School in Maiduigiri (Isah \& Yakubu, 2018). In October 2, 2012, over 40 students were murdered in cold blood at Federal Polytechnic, Mubi, Adamawa. In 2014, Nigeria witnessed the abduction of 276 Chibok girls while in the school. The kidnapping of the students attracted global outrage even in form of protests. Some of the girls are yet to return to their homes after several years. The activities of Boko Haram group created a new dimension to Nigeria insecurity challenge. There were cases of abductions of teachers and students from Lagos Junior Model College, Igbonla on October 6, 2016. There were also cases of killing of students and teachers with bombs denoted even in school assemblies. On November 16, 2021, it was reported that Boko Haram insurgents have taken over five (5) communities in Rafi and Shiroro local councils of Niger State (The Guardian, 16 November, 2021).

Isah \& Yakubu, 2018, opined that since insurgency is an attempt to take confront and overthrow an existing government for the control of power, resources for power sharing, acts of insurgency by Boko Haram is a treasonable offence and must be treated accordingly. According to African Centre for Strategic Studies (2015), the fluctuating tactics used by government in handling Boko Haram insurgency ranging from high handedness and passive responses has not been able to stem the activities of the organization or dismantle it due to Nigeria's political patronage system and high level of corruption.

\section{Banditry}

Within the last one year, abductions of students and school staff by bandits seem to have become a trend. The Cable (2021) reported that on December 11, 2020, 344 male students were abducted from their hostels in Government Science Secondary School, Kankara, Katsina State. Two weeks later, on December 20, 2020,80 pupils of the Islamiyya School, Mahuta, Kaduna State were abducted. Furthermore, on February 17, 2021,27 students were abducted from GSS College, Kagara, Niger State. In Zamfara State, 279 girls were abducted on February 26, 2021. The Federal College of Forestry Mechanisation, Afaka, Kaduna State also had 39 of her 
students kidnapped on March11, 2021(Premium Times, 2021). The bandits attacked again on April 20, 2021 and kidnapped 23 students of Greenfield University, Kaduna State (The Guardian, 2021). Three (3) more students were kidnapped on April 24, 2021 from Federal University of Agriculture, Makurdi, Benue State. Most recently, six (6) University of Abuja officials and family members were kidnapped from the University staff quarters on November 2, 2021 (African Research Bulletin, 2021). Although some of the victims of these abductions have been released some have lost their lives unfortunately. Banditry has unfortunately become a platform used by aggrieved elements to abduct school age children, students and staff from their schools to force those in government to negotiate with them.

Several states in Nigeria in response to the act of terrorism towards young ones seeking education have shut down boarding schools. Consequently, keeping schools closed is adding to over 13.5 million out-of-school children in Nigeria resulting to poverty, child labour and early marriages of the girls (Dami, 2021). Government should adopt stiffer approach to dealing with banditry and every form of terrorism especially as it affects education. The Lagos State House of Assembly has passed a bill that places death penalty on kidnapping.

\section{Secondary School Administration}

School as a system depends on external influences. They are affected by the level of crime, victimization and violence in the society. Insecurity situations promote fears of lives and property and the challenges of insecurity need to be effectively handled for sustenance of education in Nigeria. The administration of the education system in Nigeria is carried out through the ministries of education at the federal and state levels in conjunction with the statutory bodies referred to as commissions. The Federal Ministry of Education is responsible for coherence of the national policy and procedures and for ensuring the state policies operate within the parameters of the national policy (Ogunode, Ahaotu,\& Obi-Ezenekwe(2021). Cordination of policy on education at the political level is handled by the National Council of Education. The National Council of Education is the highest policymaking body chaired by the Federal Minister of Education and all the State Commissioners of Education. The body advises the Joint Consultative Committee on Education, which consists of all the Federal and State Directors of Education, Chief Executives of Education Statutory bodies and Directors of University Institutes of Education.

\section{Secondary School administration and challenges of insecurity}

Phenson, Ojie, Esin and Atai, 2014 outlined some of the security challenges faced by school administration as follows:

- Inadequacies in manpower recruitment and training of security forces and law enforcement agencies.

- Lack of timely and promptness in the handling of security issues by government.

- Lack of citizens' involvement in state security management.

- Low standard of security awareness.

- Reluctance by citizens to volunteer security information to law enforcement agencies.

- Slow threat response by government to security advices on threat assessment and neutralization.

- Lack of effective coordination and harnessing of human material and technical resources.

- Poor funding of security agencies and low motivation of security personnel.

- Lack of effective security networking between security and law enforcement agencies.

- Lack of security personnel's self-control and discipline.

- Lack of secrecy and porous security network

- Non-adherence to document security classification and violation of Oaths of Secrecy Acts in security and government departments in Nigeria.

Fleet (2015) enumerated expected roles and responsibilities of school administrators in the overall interest of ensuring safety in schools as:

- Reinforcement of School Infrastructural facilities:

This may be in the form of providing basic and cost effective mechanisms that creates boundary walls and/or the installation of barbed wire in order to thwart attacks or any form of abductions directed at schools.

- Provision of Armed Guards in Schools:

In liason with the relevant law enforcement agencies, proprietors can also provide armed guards that can serve the purpose of either repelling attacks or intimidating likely attacks.

- Providing Security Awareness Training for all Staff:

Members of staff should be made to undergo safety and security awareness trainings. The aim is to help them recognize warning signals and alerting local and law enforcement authorities.

- Having a School Security Plan and Response System:

Proprietors should consider as topmost priority the need to have a detailed security plan in view of the evolving security challenges in recent times. Guidance in formulating the security plan should be sort 
from the local and law enforcement authorities. All students and staff should be familiar with such plans and rapid response system instituted with the aim of implementing a contingency plan in the event of an attack while also restoring situation back to normalcy.

\section{Adopting Good Governance in Addressing Insecurity Challenges in Nigeria}

Good governance places emphasis on using the strategies of transparency, responsibility and accountability in the administration of a nation. Good governance also ensures the rule of law, promotes due process, improves efficiency, salutes excellence; insist on productivity and delivers high quality services to the people (Ibrahim, 2013). To achieve effective results, some of the measures that must be adopted to grapple insecurity in Nigeria include:

i. Employment creation for the youths

The effects of unemployment could lead to involvement in crimes mostly among youths. Government must encourage and support private sector to create jobs. Constant electricity supply and other infrastructural projects to boost employment in private sector need to be urgently attended to by the government agencies in charge of them.

ii. Equipping Security Agencies

Training and retraining of officers of security agencies must be carried out on regular basis with special focus on human rights, weapon handling, communication skills, new interrogation techniques, exposure to new equipment and technology (Okonkwo et al, 2015). It is very important that security agencies be equipped with modern arms and ammunition because most of our law enforcement officers carry outdated weapons.

iii. Eliminating corruption

Elimination of corruption is closely related to building trust and is beyond allocating funds for developmental initiatives. It requires the establishment of quality public goods such as roads, health services and other infrastructures equitably especially in areas where there are perceptions of marginalization.

iv. Creation of transparent and participatory political system

Eliminating corruption will entail political and public leaders acting with transparency and accountability in the allocation and implementation of projects. Favoritism and nepotism should be eradicated.

\section{Conclusion}

The safety and security of all school members is paramount for schools, colleges, polytechnics and universities to continue functioning as institutions of learning. It befalls on government in the practice of good governance to protect lives and property of the citizenry. Participatory political system which accepts more input from citizens to articulate the injustices they have suffered and engage transparency in sharing of the national resources to stem insecurity in the nation. The National Council on Education and school administrators at the lower levels with law enforcement agencies should establish mechanisms to ensure safety and security of students and staff in schools nationwide.

\section{Suggestions}

- School administrators who understand their roles and responsibilities in ensuring safety schools should be appointed. This duty needs to be carried out with all diligence with the cooperation of staff and students.

- Security awareness and orientation aimed at sensitizing the public should be considered as topmost priority by the relevant agencies of government. Nigerians should be regularly sensitized on ways of promoting security at schools, streets, highways and homes.

- Government should engage the regions in Nigeria through provision of public goods to diminish the perception of deprivation and inequality.

- The basic needs of man in any civilized society are survival and safety. The basic needs of education, employment, appropriate information must be provided.

\section{References}

Achumba, I. C., Ighomereho, O. S. and Akpor-Robaro, M.O. M. (2013). Security Challenges in Nigeria and the Implications for Business Activities and Sustainable Development, Journal of Economics and Sustainable Development, 4(2), 79-99.

Adeosun, A. B. (2012). Nigeria at 50: The Role of Good Governance and Effective Public Administration Towards Achieving Economic Growth and Stability in Fledgling Democracy. International Journal of Politics and Good Governance, 3(3), 1-17.

Aina, J. K., Gana, N.N. \& Ibitomi, O. O. (2017). The Lack of Good Governance in Nigeria and its Impact on Functional Science Education. International Journal of Development and Sustainability, 6(9), 1-12. 
African Research Bulletin: Political, Social and Cultural Series, Nigeria's Security Cases- Five Different Threats 58(4), 23135B-23138A. Retrieved: 24/11/2021.

African Centre for Strategic Studies (2015). Fundamental Security Challenges Nigeria Must face Part 8: Governance http://africacenter.org Retrieved: 15/11/2021.

Dami, D. D. (2021). Impact of Terrorism, Banditry and Kidnapping on Human Security in Nigeria. Saudi Journal of Humanities and Social Societies 6(8), 299-305.

Fleet, J. (2015). Safe School Initiative: Protecting the Right to Learn in Nigeria. A Business Coalition for Education in Collaboration with: A World at School. httpp://gbc-education.org. Retrieved: 15/11/2021.

HumAngle, 2021. Nearly 6000 Lives Lost to Insecurity in First Half of 2021 Across Nigeria. Retrieved 12/11/2021.

Ibrahim, A. (2013). Issues in Security, Good Governance and its Challenges to Economic Growth and Development, Mediterraean Journal of Social Science, 4(13), 187-191.

Isah, E. A. \& Yakubu, S. (2018).Insurgency and Secondary Schools' Safety in Nigeria's North-East Region, African Journal of Educational Management 19(1), 119-134.

Ishaq, A B. Musa, T. A. \& Abdulhafiz, Z. (2019). Education and Insecurity in Nigeria. http//researchgate.net. Retrieved; $15 / 11 / 2021$.

Nearly 6000 lives lost to insecurity in first half of 2021 across Nigeria. Humananglemedia.com Retrieved: $15 / 11 / 2021$

Nwosu, C. A., Ukwunna, J., Ebokaiwe, C. \& Ukwunna, G. C. (2019). Insecurity and the Nigeria School System: The Securitization Option for Sustainable Development. $2^{\text {nd }}$ International Conference of Unizik Business School.

Theme:Re-engineering Africa's Economies Towards Sustainable Development. Venue: University Auditorium, Unizik, Awka, Anambra State, Nigeria.

Ogunode, N. J., Ahaotu, G.N. \& Obi-Ezenekwe, U.N. (2021). Effects of Insecurity on School Administration in Nigeria. Middle European Scientific Bulletin, 13(1), 93-102.

Okonkwo, R. I., Ndubuisi-Okolo, P. \& Anagbogu, T. (2015). Security Challenges and the Implications for Business Activities in Nigeria: A critical review, 9(2).157-158.

Omede, A. J, (2011). Nigeria Analysing the Security Challenges of Goodluck Jonathan Administration, Canadian Social Science, 7(5), 90-102.

Otite, E. (2012). State of Insecurity in Nigeria: A challenge to the Government. http://nnn.com.ng/?page id=4449 Retrieved:15/11/2021.

Phenson,U. A., Ojie, P. A., Esin, J. O. \& Atai, A. J. 2014. Essential elements of and their Applications in Ensuring Stability and Integration of Nigeria. International Journal of Poiltics and Good Governance 5(3).

Premium Times (2021). 27 kidnapped Kaduna College Students Freed. Alfred Olufemi. http:www.premiumtimesngcom.Retrieved: 15/11/2021.

Simonies, U. E. (2004). Defining Good Governance: The Conceptual Competition is on, WZB Discussion Paper, No. P 2004-005. Wissenschaftszentrum Berlin fur Sozialforschung WZB, Berlin.

The Cable (2021) Insecurity is crippling Nigeria's education system-here's what we must do. http:www.thecable.ng Retrieved: 15/11/2021.

The Guardian, (2021). Boko Haram seizes Shiroro, Rafi LGs in Niger Odita S., Sodiq, O.,Njadvara, M. Abdulganiyu A. Joseph, W. http//:www.guardian.ng Retrieved: 16/11/2021.

The Guardian (2021).Greenfield University Abduction: 14 Students region Freedom. http//:www.guardian.ng. Retrieved 24/11/2021.

Udoh, E. W. (2015). Insecurity in Nigeria: Religious and Cultural Implications, Journal of Philosophy, Culture and Religion, 5(1), 1-7.

Ukpong-Umo, R. E. (2016). Insurgency in Nigeria and the Challenge of Nationhood, Nigerian Journal of Rural Sociology, 16(3), 64-69. 